\title{
Co-Occurrence of Intracranial Rosai-Dorfman Disease and Langerhans Histiocytosis of the Skull: Case Report and Review of Literature
}

\author{
Intrakraniyal Rosai-Dorfman Hastalığı ve Kafatasının Langerhans \\ Hücreli Histiyositozunun Aynı Zamanda Görülmesi: Olgu Sunumu ve \\ Literatür Derlemesi
}

Shankar Ayyappan KUTTY'1, Sreekala SREEHARI ${ }^{2}$

${ }^{1} N M C$ Specialty Hospital, Department of Neurosurgery, Abu Dhabi, United Arab Emirates

${ }^{2} N M C$ Specialty Hospital, Department of Pathology, Abu Dhabi, United Arab Emirates

Corresponding Author: Shankar Ayyappan KUTTY / E-mail: thinavila@yahoo.com

\begin{abstract}
Rosai-Dorfman Disease involves histiocytic proliferation of the lymphatic system. Extranodal disease involving the central nervous system is uncommon. Furthermore, the combination of this disease entity with Langerhans cell histiocytosis is an even rarer phenomenon that has only recently been highlighted.

A young male, who had previously undergone surgical excision of a skull lesion that was reported as Langerhans histiocytosis presented with an intracranial lesion mimicking a meningioma. Histopathology of the lesion was reported as being consistent with Rosai-Dorfman disease and the patient is currently undergoing chemotherapy.

This is only the second report of the co-occurrence of Langerhans histiocytosis and Rosai-Dorfman disease in the cranium and intracranial cavity. The possibility that the diseases represent different spectra of the same underlying pathology is one that merits more detailed analysis, especially at the genomic level.
\end{abstract}

KEYWORDS: Rosai-Dorfman disease, Intracranial, Langerhans cell histiocytosis, Co-Occurrence, Skull, Eosinophilic granuloma

öz

Rosai-Dorfman Hastalığında lenfatik sistemde histiyositik proliferasyon görülür. Merkezi sinir sistemini tutan ekstranodal hastalık nadirdir. Ayrıca bu hastalığın Langerhans hücreli histiyositoz ile kombinasyonu ancak yakın zamanlarda vurgulanmış olan daha da nadir bir fenomendir. Daha önce Langerhans hücreli histiyositoz olarak bildirilen bir kafatası lezyonunun cerrahi eksizyonu yapılmış genç bir erkek, menenjiyoma benzeyen intrakraniyal bir lezyonla geldi. Lezyon histopatolojisi Rosai-Dorfman hastalığı ile uyumlu olarak bildirildi ve hasta halen kemoterapi almaktadır.

Bu olgu, kraniyum ve intrakraniyal boşlukta Rosai-Dorfman hastalığı ve Langerhans histiyositozunun birlikte görüldüğü sadece ikinci olgu raporudur. Hastalıkların aynı patolojinin farklı spektrumlarını temsil etme olasılığı özellikle genomik seviyede daha ayrıntılı incelenmelidir.

ANAHTAR SÖZCÜKLER: Rosai-Dorfman hastalığı, İntrakraniyal, Langerhans hücreli histiyositoz, Birlikte görülme, Kafatası, Eozinofilik granülom

\section{INTRODUCTION}

Intracranial Rosai-Dorfman disease (RDD) is a rare, but well recognized clinical entity that needs to be differentiated from plasmacyte-rich meningiomas. Langerhans cell histiocytosis $(\mathrm{LCH})$ is a more common disorder that frequently involves the skull bones. However, the combination of these two disorders occurring in the same patient is extremely rare. Of the 12 cases reported in literature $(5,15,18,21)$, only one had both lesions occurring in the intracranial compartment (5). We present a young male who developed calvarial LCH followed 2 years later by intracranial RDD in an adjacent location. The current literature and treatment options are reviewed.

\section{CASE REPORT}

A 31-year-old male of Asian origin presented with two episodes of focal motor seizures involving the right upper limb, with secondary generalization and post-ictal weakness of the right upper limb. He had earlier undergone a left frontal craniectomy and cranioplasty for an osteolytic skull lesion with a large extracranial component, which had been reported as LCH. This had been based on the typical appearance of the lesion on histopathology, with extensive histiocytic infiltration. An MRI of the brain with contrast showed a large, enhancing, dural based mass lesion in the left posterior frontal and parietal region with significant perilesional edema (Figure 1). The dura surrounding the lesion was also enhancing with 
contrast, and the image characteristics were consistent with a radiological diagnosis of a meningioma. There was another small $(1 \mathrm{~cm})$ lesion in the anterior frontal area, which was also enhancing with contrast.

He underwent a left parietal craniotomy and excision of the mass under general anesthesia. The dura was found to be diffusely thickened in all directions. The lesion was firm, grayish white in color and relatively avascular. It was totally excised along with the surrounding dura. During the immediate post operative period, he had slight worsening of power in the right upper limb, but this recovered within 3 weeks with physiotherapy.

Grossly, the cut sections of the tumor were grey-white and homogenous with no areas of necrosis. It also demonstrated a vague fibrous appearance. Microscopically, the sections showed sheets of spindle fibroblastic proliferation in whorls and fascicles with collections of inflammatory cells composed of histiocytes, lymphocytes and plasma cells (Figure 2). There was no evidence of meningothelial nodules, but a spindle cell arrangement and histiocytic collections were noted (Figure 3).

The initial differential diagnoses considered in our case were inflammatory myofibroblastic tumour, plasma cell rich meningioma and inflammatory histiocytic lesions versus Langerhans cell histiocytosis. Langerhans histiocytes with their folded nuclei and eosinophil infiltrates were conspicuously absent in the intracranial lesion, as against their presence in the osteolytic lesion that had been excised two years earlier.

With this background a panel of immunohistochemistry was done to reach the final diagnosis. EMA and PR were negative, and this along with the lack of typical meningothelial nodules even after examining the entire tissue ruled out the diagnosis of meningioma.

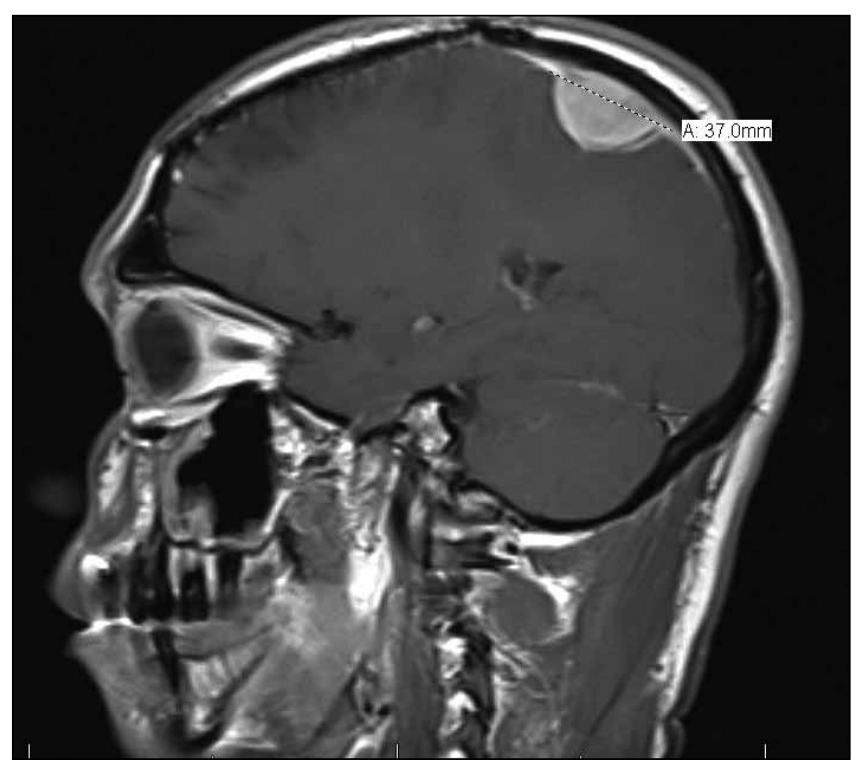

Figure 1: Sagittal MRI scan with contrast showing the enhancing lesion and the dural tail.
Alk1 was negative and the cells were positive for SMA and Vimentin, which ruled out the diagnosis of inflammatory myofibroblastic tumour. So also the further sections highlighted the sheets of histiocytes with emperipolesis (22) and lack of eosinophils, which were highly characteristic of RDD. Nodular lymphoid aggregates and plasma cell collections were seen. This along with S-100 protein and Ki-1 positivity clinched the diagnosis of Rosai-Dorfman disease.

He was referred to the Oncologist for further evaluation and management, as there was a small lesion in the frontal region which could also represent the same pathology.

\section{DISCUSSION}

Rosai-Dorfman disease (RDD) was first described by Lucien Destombes (6) in 1965 and was recognized as a distinct clinicopathologic entity by Juan Rosai and Ronald Dorfman in 1969 (17). A review in 2005 by Hargett and Bassett found over 750 cases in literature (9). RDD is an idiopathic histiocytic proliferation affecting lymph nodes, with extranodal

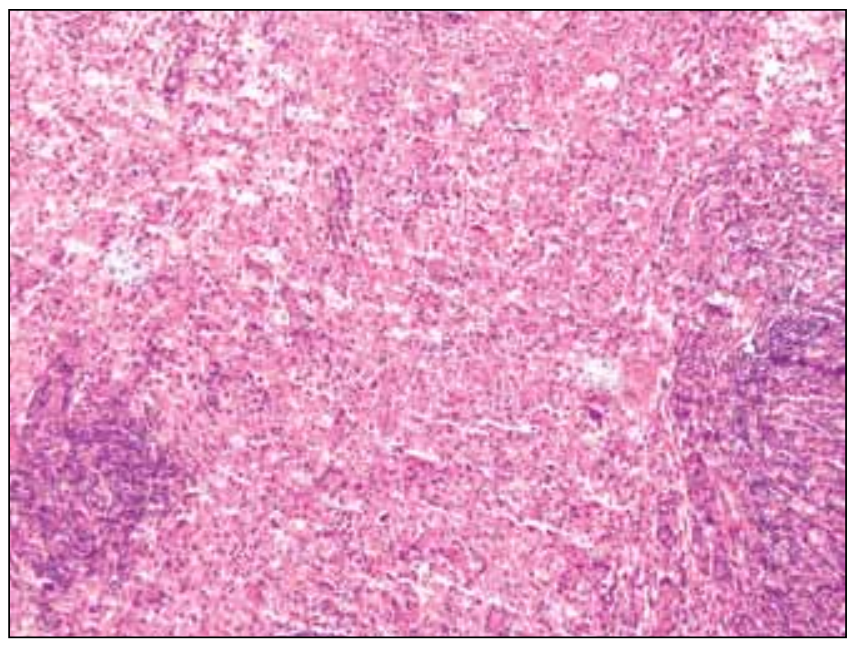

Figure 2: Dura with H\&E stain, 100x.

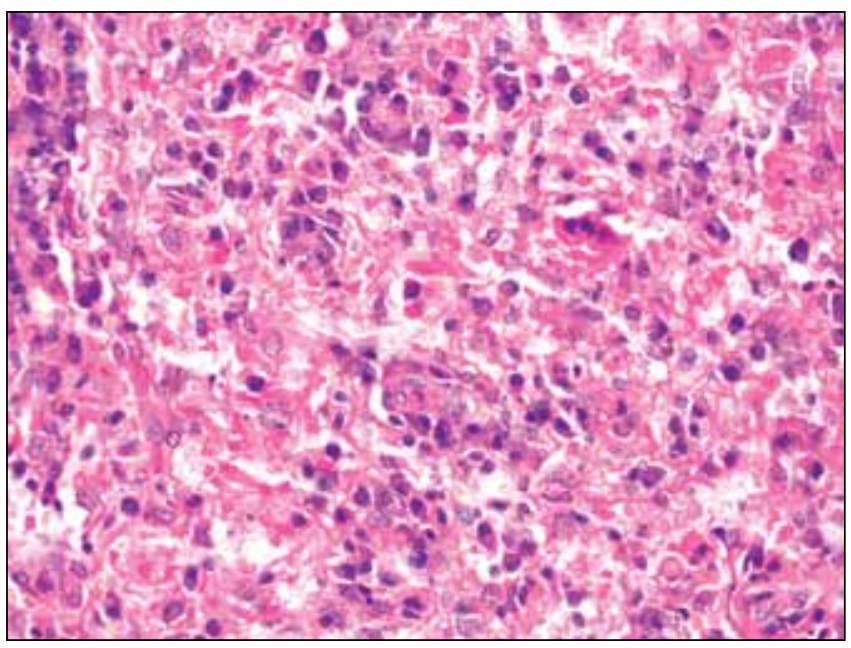

Figure 3: Dura with H\&E stain, 400x, showing extensive histiocytosis. 
involvement being reported in up to $43 \%$ of cases. Of these less than $5 \%$ show evidence of central nervous system and in $90 \%$ of these cases, the leptomeninges are afflicted (11).

Over 50 patients with Rosai-Dorfman disease involving the CNS have been reported $(3,8,19)$. CNS Rosai-Dorfman disease shows a predilection for males, and typically presents during the 4 th to 5 th decade with the mean age of 39.4 years old (13).

Histopathologically, a sheet like or interspersed pattern of lymphocytes and histiocytes, with the latter demonstrating emperipolesis, is characteristic of RDD. Occasional neutrophils and eosinophils may be seen and background fibrosis may be noted in extranodal disease. On immunohistochemical examination, histiocytes are immunoreactive for S-100 protein, HAM 56, a1 antitrypsin, a1 chymotrypsin, lysozyme, Mac 387 and Ki-1, but CD $1 \mathrm{a}$ and EMA are negative $(2,10,16,20)$.

Our case was interesting because with the past history of $\mathrm{LCH}$ and the radiological features and gross morphology of a meningioma in the present lesion, the histopathology was critical in redefining the management plan. While a meningioma could have been followed up with serial imaging after total excision, a diagnosis of RDD meant that he would have to undergo chemotherapy to prevent recurrence.

Langerhans cell histiocytosis $(\mathrm{LCH})$ is a rare disease of neoplastic proliferation of monocyte-macrophage system, resulting in abnormal accumulation of activated dendritic cells and macrophages, also known as histiocytes, in various tissues. Bones are commonly affected and unifocal disease (previously known as eosinophilic granuloma) may be mistaken for osteomyelitis or primary malignancy of the bone. The lesions are characterized by Langerhans cells which are bone marrow derived cells of dendritic cell line with antigen presenting and processing properties $(1,4,12)$.

RDD and LCH occurring in the same individual is an extremely rare occurrence, with only 12 reported cases in literature $(5$, $15,18,21)$. In these patients, the lesions showed evidence of both diagnoses simultaneously, except in two cases. One patient presented as LCH initially and a recurrence 10 months later showed only RDD (15). This was similar to our patient, who developed RDD two years after a diagnosis of bony $\mathrm{LCH}$. The second case was undergoing chemotherapy for $\mathrm{LCH}$, when he developed cutaneous papules that were diagnosed as RDD (21). However, we believe that this is the first report in literature of the two lesions occurring in the skull and intracranial compartment. The co-occurrence of these two disease entities have led to the hypothesis that they may have comparable cytokine-mediated mechanisms or that both manifestations could be due to divergent differentiation from a common precursor, or that the histiocytes have undergone a phenotypic switch $(15,18)$. The latter is particularly relevant when RDD follows LCH, where prior chemotherapy may have induced a change in the histiocytes.

While some patients have shown spontaneous resolution of the lesion, total surgical excision appears to be the treatment of choice in intracranial RDD, especially when the lesions produce mass effect. Where this is not possible, as in our case with diffuse infiltration of the dura, adjuvant chemotherapy, radiotherapy or prolonged steroid therapy may be useful in controlling the disease $(7,14)$.

\section{CONCLUSION}

RDD and LCH occurring in the same patient is very rare but is being recognized more often with modern histopathological techniques. Though there are various postulates for this phenomenon, such as the two diseases representing different poles of the same spectrum or the Rosai-Dorfman disease being the result of chemotherapy induced changes in patients with LCH, the exact pathology can be elucidated only when more patients are available for detailed genomic studies.

\section{REFERENCES}

1. Ahmed M, Sureka J, Koshy CG, Chacko BR, Chacko G: Langerhans cell histiocytosis of the clivus: An unusual cause of a destructive central skull base mass in a child. Neurol India 60: 346-348, 2012

2. Andriko JA, Morrison A, Colegial CH, Davis BJ, Jones RV: RosaiDorfman disease isolated to the central nervous system: $A$ report of 11 cases. Mod Pathol. 14: 172-178, 2001

3. Azoulay R, Brisse H, Freneaux P, Ferey S, Kalifa G, Adamsbaum C: Lacrimal location of sinus histiocytosis (Rosai-DorfmanDestombes disease). AJNR 25: 498-500, 2004

4. Azouz EM, Saigal G, Rodridgez MM, Podda A: Langerhans' cell histiocytosis: Pathology, imaging and treatment of skeletal involvement. Pediatr Radiol 35: 103-115, 2005

5. Cohen-Barak E, Rozenman D, Schafer J, Krausz J, DodiukGad R, Gabriel H, Shani-Adir A: An unusual co-occurrence of Langerhans cell histiocytosis and Rosai-Dorfman disease: Report of a case and review of the literature. Int J Dermatol 53(5):558-563, 2014

6. Destombes P: Adenitis with lipid excess, in children or young adults, seen in the Antilles and in Mali (4 cases). Bull Soc Pathol Exot Filiales 58: 1169-1175, 1965, (in French)

7. Di Rocco F, Garnett MR, Puget S, Pueyerredon F, Roujeau T, Jaubert F, Sainte-Rose C: Cerebral localization of RosaiDorfman disease in a child. J Neurosurg 107 Suppl 2:147-151, 2007

8. Gupta DK, Suri A, Mahapatra AK, Mehta VS, Garg A, Sarkar C, Ahmad FU: Intracranial Rosai-Dorfman disease in a child mimicking bilateral giant petroclival meningiomas: A case report and review of literature. Childs Nerv Syst 22:11941200, 2006

9. Hargett C, Bassett T: Atypical presentation of sinus histiocytosis with massive lymphadenopathy as an epidural spinal cord tumor: A case presentation and literature review. J Spinal Disord Tech 18: 193-196, 2005

10. Huang HY, Liang CL, Yang BY, Sung MT, Lin JW, Chen WJ: Isolated Rosai-Dorfman disease presenting as peripheral mononeuropathy and clinically mimicking a neurogenic tumor. Surg Neurol 56: 344-347, 2001 
11. Kattner KA, Stroink AR, Roth TC, Lee JM: Rosai-Dorfman disease mimicking parasagittal meningioma: Case presentation and review of the literature. Surg Neurol 53: 452-457, 2000

12. Khung $S$, Budzik JF, Amzallag-Bellenger $E$, Lambilliote $A$, Soto Ares G, Cotten A, Boutry N: Skeletal involvement in Langerhans cell histiocytosis. Insights Imaging 4(5): 569-579, 2013

13. Kumar R, Singhal U, Kumar Mahapatra A: Intracranial RosaiDorfman syndrome: Case review. Pan Arab J Neurosurg 15: 58-63, 2011

14. Mahzoni $\mathrm{P}$, Zavareh $\mathrm{MH}$, Bagheri $\mathrm{M}$, Hani N: Moqtader $\mathrm{B}$. Intracranial Rosai Dorfman disease. J Res Med Sci 17(3): 304307,2012

15. O'Malley DP, Duong A, Barry TS, Chen S, Hibbard MK, Ferry JA, Hasserjian RP, Thompson MA, Richardson MS, Jaffe R, Sidhu JS, Banks PM: Co-occurrence of Langerhans cell histiocytosis and Rosai-Dorfman disease: Possible relationship of two histiocytic disorders in rare cases. Mod Pathol 23(12): 16161623,2010
16. Raslan O, Ketonen LM, Fuller GN, Schellingerhout D: Intracranial Rosai-Dorfman disease with relapsing spinal lesions. J Clin Oncol 26: 3087-3089, 2008

17. Rosai J, Dorfman RF: Sinus histiocytosis with massive lymphadenopathy: A newly recognized benign clinicopathological entity. Arch Pathol 87: 63-70, 1969

18. Sachdev R, Shyama J: Co-existent Langerhans cell histiocytosis and Rosai-Dorfman disease: A diagnostic rarity. Cytopathology 19(1): 55-58, 2008

19. Ture U, Seker A, Bozkurt SU, Uneri C, Sav A, Pamir MN: Giant intracranial Rosai-Dorfman disease. J Clin Neurosci 11: 563-566, 2004

20. Walid MS, Grigorian AA: Ethmo-spheno-intracranial RosaiDorfman disease. Indian J Cancer 47: 80-81, 2010

21. Wang $\mathrm{KH}$, Cheng $\mathrm{CJ}, \mathrm{Hu} \mathrm{CH}$, Lee WR: Coexistence of localized Langerhans cell histiocytosis and cutaneous Rosai-Dorfman disease. Br J Dermatol 147(4): 770-774, 2002

22. Weedon's Skin Pathology. 3rd ed. Weedon D (ed) Australia: Elsevier, Churchill Livingstone, 2010 